\title{
Comparison of outer-membrane proteins of Pasteurella haemolytica expressed in vitro and in vivo in cattle
}

\author{
R. L. Davies, ${ }^{1}$ J. McCluskey, ${ }^{1}$ H. A. Gibbs, ${ }^{2}$ J. G. Coote, ${ }^{1}$ J. H. Freer ${ }^{1}$ and \\ R. Parton ${ }^{1}$
}

Author for correspondence: R. L. Davies. Tel: +44 413398855 ext. 6685. Fax: +44 413304600 .

Departments of Microbiology ${ }^{1}$ and Veterinary Medicine², University of Glasgow, Glasgow G12 8QQ, UK

\begin{abstract}
Outer-membrane protein (OMP) profiles of two serotype A1 isolates of Pasteurella haemolytica were compared by SDS-PAGE and Western blotting with bovine convalescent serum after growth (a) in vitro under iron-sufficient and-deficient conditions, (b) in vivo in the lungs of experimentally infected calves and $(c)$ in vivo in diffusion chambers implanted into the peritoneal cavities of calves. Lung-grown bacteria differed from iron-sufficient in vitrogrown bacteria in having enhanced expression of the previously recognized 71 , 77 and $100 \mathrm{kDa}$ iron-regulated proteins, reduced expression of 18, 31, 39.5 and $50 \mathrm{kDa}$ proteins, and expression of a $19 \mathrm{kDa}$ protein. Differences were also apparent in the Western blot profiles of OMPs of in vitro- and lung-grown bacteria. These included the apparent lack of recognition of the $100 \mathrm{kDa}$ protein in the lung-grown bacteria, but not in the in vitro-grown bacteria, and more intense staining of a $47 \mathrm{kDa}$ protein in in vitro-grown bacteria, but not in lung-grown bacteria. The OMP profiles of the chamber-grown bacteria resembled those of the lung-grown bacteria in that expression of the 18, 19, 31 and $39.5 \mathrm{kDa}$ proteins was similar. These similarities demonstrated that the chamber-grown bacteria had adapted to the in vivo environment, and that growth conditions within the chambers resembled, but not perfectly, those within the lungs. For example, expression of the three iron-regulated OMPs was very low in the chamber-grown bacteria compared to the lung-grown bacteria. The OMP profiles of bacteria grown in vitro in newborn calf serum closely resembled those of lung-grown bacteria, suggesting that in vivo growth may be partly reproduced in vitro by growing the bacteria in newborn calf serum.
\end{abstract}

Keywords: Pasteurella baemolytica, outer-membrane proteins, bovine pneumonic pasteurellosis

\section{INTRODUCTION}

Pasteurella baemolytica is an economically important respiratory pathogen of cattle, responsible for pneumonic pasteurellosis, a severe fibrinous pleuropneumonia (Frank, 1989). The bacterium also causes pneumonia and septicaemia in sheep (Gilmour \& Gilmour, 1989). Bovine pneumonic pasteurellosis is due predominantly to isolates of serotype A1, whereas the single most predominant serotype from pneumonic sheep is A2 (Frank, 1989; Gilmour \& Gilmour, 1989). Vaccines against bovine

Abbreviation: OMP, outer-membrane protein. pneumonic pasteurellosis, including live, killed and extract vaccines, have not been particularly effective in reducing losses (reviewed by Mosier et al., 1989). Very little is known about the role of the different cell-surface components, including the capsule, lipopolysaccharide (LPS) and outer-membrane proteins (OMPs), in the pathogenesis of pneumonic pasteurellosis. Recent research has attempted to identify important immunogenic components of $P$. baemolytica, such as LPS (Confer $e t$ al., 1986; Davies et al., 1991; Ali et al., 1992) and various OMPs (Nelson \& Frank, 1989; Knights et al., 1990; Craven et al., 1991; Davies et al., 1992; McCluskey et al., 1994), including iron-regulated OMPs (Donachie \& Gilmour, 1988; Deneer \& Potter, 1989; Gilmour et al., 
1991). However, these investigations have involved the analysis of in vitro-grown organisms as opposed to in vivogrown organisms.

It is now well recognized that pathogenic bacteria may express different cell-surface components when growing in vivo and in vitro (Brown \& Williams, 1985; Smith, 1990). For example, pathogenic Gram-negative bacteria may produce a number of iron-regulated OMPs when growing in vivo which are not produced, or are produced less abundantly, when growing in vitro under iron-sufficient conditions (Griffiths et al., 1983; Sciortino \& Finkelstein, 1983; Brown et al., 1984). P. baemolytica produces three iron-regulated OMPs of 71,77 and $100 \mathrm{kDa}$ under ironrestricted in vitro growth conditions (Donachie \& Gilmour, 1988; Deneer \& Potter, 1989; Davies et al., 1992). The $100 \mathrm{kDa}$ protein has been demonstrated to be the receptor for bovine transferrin (Ogunnariwo \& Schryvers, 1990). Previous studies on the in vivo expression of OMPs in $P$. baemolytica have produced conflicting results regarding the expression of the iron-regulated OMPs. These differences may be due to strain or serotype variations, to the use of different animals for the in vivo studies, or to the growth characteristics of the bacteria at different sites. Morck et al. (1991) demonstrated in vivo expression of the 71,77 and $100 \mathrm{kDa}$ OMPs in a serotype A1 isolate grown in a peritoneal implant chamber in a rabbit: all three proteins were recognized by bovine convalescent antiserum. In a study of a serotype A2 isolate, grown in the pleural fluid of a sheep, Donachie \& Gilmour (1988) demonstrated in vivo expression of 71 and $100 \mathrm{kDa}$ OMPs, but not of a $77 \mathrm{kDa}$ OMP. These authors, furthermore, demonstrated antibody recognition of the $71 \mathrm{kDa}$ OMP, but not of the $100 \mathrm{kDa}$ OMP in lamb convalescent antiserum. Confer et al. (1992) examined whole-cell profiles of serotype A1 cells obtained from a subcutaneous chamber implanted into a calf, and were able to detect differences between in vitro- and in vivogrown cells only in proteins of 24,26 and $>150 \mathrm{kDa}$, but it was not confirmed whether these proteins were located in the outer membrane. Sutherland et al. (1990) examined the whole-cell profiles of a serotype A2 isolate, grown in implant chambers in the peritoneal cavity of a sheep, and demonstrated enhanced production of 71 and $100 \mathrm{kDa}$ proteins; these proteins were not, however, recognized by antibodies in Western blots.

None of the above in vivo studies attempted to examine the expression of OMPs of $P$. haemolytica obtained directly, without subculture, from the infected lungs of calves, or to correlate the findings obtained from in vivo implant chambers with findings from infected lungs. Although an in vivo implant chamber may provide a more natural environment than a flask of broth, the conditions within a chamber may still not exactly mimic the conditions occurring at the site of the natural infection. Therefore, the objectives of the present study were twofold. Firstly, to compare the OMP profiles of two serotype A1 isolates of $P$. haemolytica grown in intraperitoneal implant chambers in healthy calves, with those of the same isolates obtained from the lungs of experimentally infected calves. Secondly, to compare the OMP profiles of in vivo-grown bacteria with the profiles of the same bacteria grown under various in vitro conditions as described previously (Davies et al., 1992), and thereby determine the in vitro growth conditions most able to reproduce the in vivo growth conditions.

\section{METHODS}

Bacterial isolates and in vitro growth conditions. Two serotype A1 isolates of $P$. baemolytica were used in the present study, PH2 (S/C 82/1) and PH10. Both isolates were obtained from confirmed cases of bovine pneumonic pasteurellosis, and possessed smooth LPS of type 1 (Davies et al., 1991; Ali et al., 1992).

Bacteria were stored at $-70{ }^{\circ} \mathrm{C}$ in brain heart infusion broth (BHIB; Oxoid) containing 50\% (v/v) glycerol and routinely subcultured on brain heart infusion agar (BHIA; Oxoid) containing $5 \%(\mathrm{v} / \mathrm{v})$ defibrinated sheep's blood. For chamber inoculations and outer-membrane preparations, bacteria were grown to early stationary phase (approximately $6 \mathrm{~h}$ ) in BHIB. All incubations were carried out at $37^{\circ} \mathrm{C}$ and broth cultures were shaken at 120 r.p.m. For iron-deficient in vitro growth, bacteria were grown in BHIB containing $20 \mu \mathrm{M}$ ethylenediaminedihydroxyphenylacetic acid (EDDA) (Davies $e t$ al., 1992).

Calves. Four-month-old weaned, dairy-cross calves were used in the experiments. Prior to use in chamber and lung infection experiments, calves were screened by indirect haemagglutination assay for antibodies to serotypes A1 and A2 (Shreeve et al., 1972).

\section{In vivo culture of bacteria}

(i) Lungs. Bacteria were grown in $200 \mathrm{ml}$ BHIB to late logarithmic phase $(4-5 \mathrm{~h})$, harvested by centrifugation at $10000 \times \mathrm{g}$ for $20 \mathrm{~min}$ and resuspended in $20 \mathrm{ml}$ PBS $(150 \mathrm{mM}$ $\mathrm{NaCl}, 7.2 \mathrm{mM} \mathrm{Na} \mathrm{HPO}_{4}, 2.8 \mathrm{mM} \mathrm{NaH} \mathrm{PO}_{4}, \mathrm{pH} 7 \cdot 2$ ). Calves were infected by the intra tracheal route as described previously (Gibbs et al., 1984), killed after $18 \mathrm{~h}$ and exsanguinated, the lungs removed, and bacteria washed from the airways in PBS. Bacteria were recovered from the lung washings by differential centrifugation. Large debris and blood cells were removed by three centrifugations at $500 \mathrm{~g}$ for $5 \mathrm{~min}$, and bacteria harvested by centrifugation at $10000 \mathrm{~g}$ for $30 \mathrm{~min}$ and resuspended in $20 \mathrm{mM}$ Tris $/ \mathrm{HCl}(\mathrm{pH} \mathrm{7.2)}$ for outer-membrane preparation. Viable counts were performed on the challenge suspension as described previously (Davies et al., 1994b).

(ii) Implant chambers. Bacteria were obtained from intraperitoneal diffusion chambers implanted into calves as described previously (Davies et al., 1994b). Due to the slow decline in bacterial numbers within the chambers over a $10 \mathrm{~d}$ period (Davies et al., $1994 b$ ), the chambers were inoculated with a high number of bacteria to give an initial cell density of approximately $5 \times 10^{9}$ c.f.u. $\mathrm{ml}^{-1}$. The bacteria within the chambers were recovered after $18 \mathrm{~h}$. Using this method, sufficient numbers of bacteria were obtained to allow preparation of outer membranes.

Preparation of outer membranes. Outer membranes were obtained by Sarkosyl extraction as described previously (Davies et al., 1992).

Protein assay. Protein concentrations of outer membrane samples were assayed by the modified Lowry procedure of Markwell et al. (1978).

SDSPAGE. OMPs were separated by SDS-PAGE using the SDS-discontinuous system of Laemmli (1970) as described 
(a)

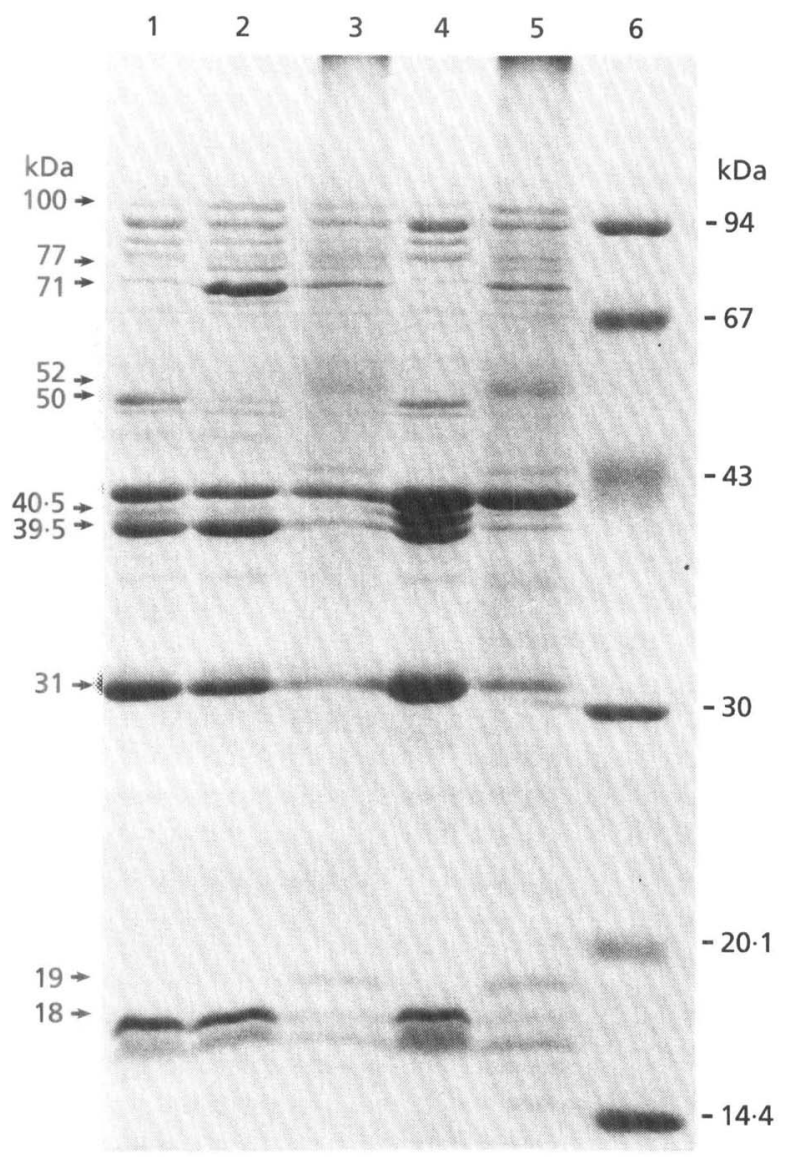

(b)

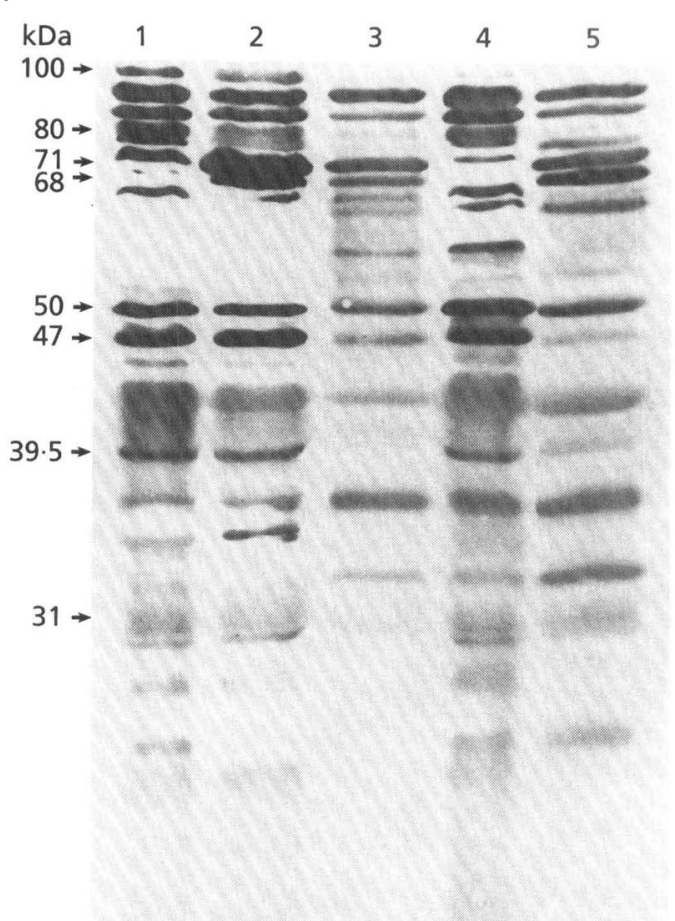

Fig. 1. Coomassie-blue-stained SDS-PAGE OMP profiles (a) and Western blot (b) of in vitro- and lung-grown cells of $P$. haemolytica isolates PH2 (lanes 1-3) and PH10 (lanes 4 and 5). Bacteria were grown in BHIB (lanes 1 and 4), BHIB supplemented with $20 \mu \mathrm{M}$ EDDA (lane 2), and in calf lungs (lanes 3 and 5). Size markers are shown in lane 6 in (a).

previously (Davies et al., 1992). Approximately $20 \mu \mathrm{g}$ OMP were loaded per well, and visualized by staining with Coomassie blue. Molecular mass standards (Pharmacia) were phosphorylase $\mathrm{b}(94 \mathrm{kDa})$, BSA $(67 \mathrm{kDa})$, ovalbumin $(43 \mathrm{kDa})$, carbonic anhydrase $(30 \mathrm{kDa})$, trypsin inhibitor $(20.1 \mathrm{kDa})$ and $\alpha$ lactalbumin $(14.4 \mathrm{kDa})$.

Western blotting. Differences in immune reactivity to in vitroand in vivo-expressed OMPs were investigated by Western blotting as described previously (Davies et al., 1994a). The primary antibody source was convalescent antiserum raised by experimental infection of a calf (Ali et al., 1992). The antiserum was used at a dilution of $1: 200$ in antibody buffer.

\section{RESULTS}

Sufficient numbers of cells of $P$. baemolytica isolates $\mathrm{PH} 2$ and $\mathrm{PH} 10$ were obtained from both infected lungs and implant chambers to extract outer membranes. OMP profiles, by SDS-PAGE, of cells obtained directly, without subculture, from the lungs of infected calves, and from implant chambers, were compared with each other and with OMP profiles of cells grown in vitro under ironsufficient and -deficient conditions. OMP profiles of in vitro- and lung-grown cells of isolates $\mathrm{PH} 2$ and $\mathrm{PH} 10$ are shown in Fig. 1(a). Isolates PH2 and PH10 were serotype
A1 isolates which have previously been shown to have slight differences in virulence but similar OMP profiles (unpublished observations). During in vitro growth, these isolates showed variation in the expression of the $40 \mathrm{kDa}$ OMP (Fig. 1a, lanes 1 and 4), although it should be noted that expression of this protein can vary within the same isolate according to the degree of aeration during growth (Davies et al., 1992). Isolates PH2 and PH10 also exhibited some variation in their Western blot profiles, during both in vitro and in vivo growth (Fig. $1 \mathrm{~b}$, lanes 1 and 4 , and 3 and 5). Important differences in the SDS-PAGE profiles between the in vitro- and lung-grown cells included the reduced expression of the 31 and $39.5 \mathrm{kDa}$ major proteins of both isolates in the lung-grown cells (Fig. 1a, lanes 3 and 5). There was enhanced expression of the 71, 77 and $100 \mathrm{kDa}$ iron-regulated proteins in the lung-grown cells of isolate PH10 (Fig. 1a, lanes 4 and 5), but this was not as evident in isolate PH2 (Fig. 1a, lanes 1 and 3). Expression of these proteins, especially the $71 \mathrm{kDa}$ protein, was not as great as when the cells were grown in BHIB in the presence of EDDA (Fig. 1a, lane 2). Further differences between the in vitro- and lung-grown profiles included reduced expression of the $18 \mathrm{kDa}$ protein, and the appearance of an additional protein of $19 \mathrm{kDa}$ in the lung- 
Table 1. Expression of OMPs from in vitro- and in vivogrown $P$. haemolytica

Expression of OMPs was graded as follows: +++ , high; ++ , moderate; + , low; - , none.

\begin{tabular}{|c|c|c|c|c|}
\hline \multirow{2}{*}{$\begin{array}{l}\text { Protein } \\
\text { (kDa) }\end{array}$} & \multicolumn{2}{|c|}{ Expression in vitro } & \multicolumn{2}{|c|}{ Expression in vivo } \\
\hline & $\begin{array}{c}\text { Iron- } \\
\text { sufficient }\end{array}$ & $\begin{array}{c}\text { Iron- } \\
\text { deficient }\end{array}$ & $\begin{array}{l}\text { Lung- } \\
\text { grown }\end{array}$ & $\begin{array}{c}\text { Chamber- } \\
\text { grown }\end{array}$ \\
\hline 18 & ++ & ++ & + & + \\
\hline 19 & - & - & + & + \\
\hline 31 & ++ & ++ & + & ++ \\
\hline $39 \cdot 5$ & ++ & ++ & + & ++ \\
\hline 71 & + & +++ & ++ & + \\
\hline 77 & + & ++ & ++ & + \\
\hline 100 & + & ++ & ++ & + \\
\hline$>100$ & - & - & + & + \\
\hline
\end{tabular}

grown cells (Fig. 1a, lanes 3 and 5). A diffuse band of approximately $52 \mathrm{kDa}$ was present in the lung-grown cells, but not in the in vitro-grown cells, whereas a protein of $50 \mathrm{kDa}$ was expressed in in vitro-grown cells, but not in lung-grown cells (Fig. 1a, compare lanes 1 and 3, and 4 and 5). The differences between OMP profiles of in vitro- and in vivo-grown $P$. baemolytica are summarized in Table 1.

The corresponding Western blot, using convalescent antiserum, showed a number of differences in antibody reactivity between the in vitro- and lung-grown OMP profiles (Fig. 1b). In neither isolate was there recognition of the $100 \mathrm{kDa}$ iron-regulated protein in lung-grown cells (Fig. 1b, lanes 3 and 5), although this protein was clearly visible in the stained gel (Fig. 1a, lanes 3 and 5). In contrast, the protein was clearly recognized by antibody in both the iron-sufficient and -deficient in vitro-grown cells of isolate PH2 (Fig. 1b, lanes 1 and 2). A wide band, possibly representing two discrete proteins, of approximate molecular mass $80 \mathrm{kDa}$ was recognized in the in vitro-grown cells, but not in the lung-grown cells of both isolates (Fig. 1b, lanes 3 and 5). The $71 \mathrm{kDa}$ protein was recognized in the lung-grown cells of both isolates, but not in the in vitro-grown cells of isolate PH10 (Fig. 1b, lane 4). A protein of approximately $68 \mathrm{kDa}$ was recognized in both lung-grown isolates, but not in the iron-sufficient in vitro-grown cells (Fig. 1b, lanes 3 and 5). A further difference was the more pronounced recognition of a protein of approximately $47 \mathrm{kDa}$ in the in vitro-grown cells compared to the lung-grown cells. Additional minor differences were also evident between the in vitro- and lung-grown cells, including weaker recognition of 50 and $18 \mathrm{kDa}$ proteins in the latter (Fig. 1b, lanes 3 and 5). It was notable that the major 39.5 and $31 \mathrm{kDa}$ proteins could not be clearly identified in Western blots (Fig. 1b). These proteins were either not very immunogenic or not very reactive in Western blots. Similar results were observed in a previous Western blot study (Davies et al., 1994a), in which replicate OMP profiles on nitrocellulose were stained with amido black for direct comparison with Western blots.

The OMP profiles of P. baemolytica isolates $\mathrm{PH} 2$ and $\mathrm{PH} 10$ obtained from intraperitoneal implant chambers were compared with those of the same isolates obtained from lungs and from cells grown in vitro under iron-sufficient or -deficient conditions (Fig. 2a). The reduced expression of the $18 \mathrm{kDa}$ protein, and apparent production of a novel $19 \mathrm{kDa}$ protein, described above in lung-grown cells, was also observed in the chamber-grown cells (Fig. 2a, lanes 3 and 4 , and 7 and 8 ). This similarity in expression of the 18 and $19 \mathrm{kDa}$ proteins, between lung- and chamber-grown cells, confirmed that the chamber-grown cells had indeed adapted to the in vivo conditions of the chamber, even though the bacterial population within the chamber was in decline (Davies et al., 1994b). The $19 \mathrm{kDa}$ protein was expressed more in lung-grown cells of isolate PH10 than in those of isolate PH2 (Fig. 2a, lane 7). In contrast to the lung-grown cells, however, the chamber-grown cells did not exhibit such extensive reduction in expression of the 39.5 and $31 \mathrm{kDa}$ major proteins (Fig. 2a, lanes 4 and 8 ). In addition, there was no enhanced expression of the three iron-regulated proteins in the chamber-grown cells, as there was in the lung-grown cells. In both isolates, there was expression of a minor high-molecular-mass protein of $>100 \mathrm{kDa}$ in chamber-grown cells, but not in in vitrogrown cells (Fig. 2a, lanes 4 and 8). A protein of similar molecular mass was also present in lung-grown cells of isolate PH2 (Fig. 2a, lane 3). In isolate PH2, but not in isolate $\mathrm{PH} 10$, two proteins of approximate molecular masses 20 and $30 \mathrm{kDa}$ were present in chamber-grown cells, but not in lung-grown or in vitro-grown cells (Fig. 2a, lane 4). A diffuse band of approximately $52 \mathrm{kDa}$ was visible in the OMP profiles of chamber-grown cells of isolates PH2 and PH10 (Fig. 2a, lanes 4 and 8) and possibly represented the bound heavy chain of IgG, as described previously (Sutherland $e t$ al., 1990). The more intense background staining along the lanes of lunggrown bacteria, particularly in Fig. 2(a), lane 7, was possibly due to contaminating surface-bound material. It was unlikely to have been bacterial capsular or LPS material, since this would also have been present in the in vitro profiles. These results are summarized in Table 1.

In convalescent serum, the pattern of antibody binding, in Western blots, to the OMPs of the chamber-grown cells was characterized by the recognition of fewer bands than for in vitro- or lung-grown cells (Fig. 2b, lanes 4 and 8). The most noticeable difference between the in vitro- and in vivo-grown cells was in the recognition of a protein of approximate molecular mass $47 \mathrm{kDa}$, which was stained intensely in the in vitro-grown cells, but poorly stained in the in vivo-grown cells (Fig. 2b, compare lanes 1 and 2 with 3 and 4 , and 5 and 6 with 7 and 8 ). In addition, there was no significant recognition of the iron-regulated proteins, especially of the 71 and $100 \mathrm{kDa}$ proteins, in the chambergrown cells. Differences in the antibody reactivity to OMPs between lung- and chamber-grown cells included the recognition of proteins of $32,34,36,55$ and $65 \mathrm{kDa}$ in lung-grown cells, but not in chamber-grown cells (Fig. $2 b$, lanes 3 and 4 , respectively). 

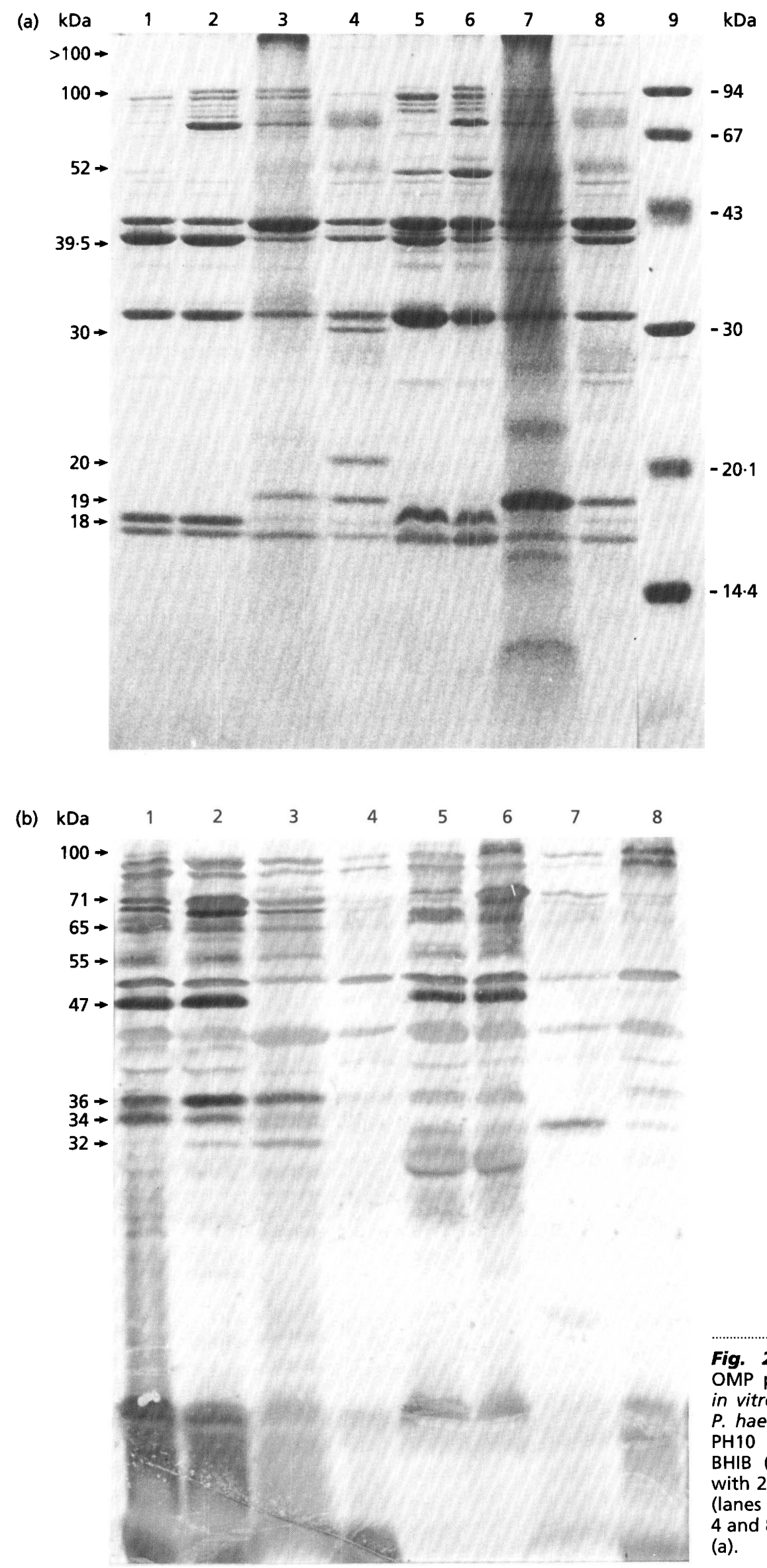

Fig. 2. Coomassie-blue-stained SDS-PAGE OMP profiles (a) and Western blot (b) of in vitro-, lung- and chamber-grown cells of P. haemolytica isolates $\mathrm{PH} 2$ (lanes 1-4) and $\mathrm{PH} 10$ (lanes 5-8). Bacteria were grown in BHIB (lanes 1 and 5), BHIB supplemented with $20 \mu \mathrm{M}$ EDDA (lanes 2 and 6), calf lungs (lanes 3 and 7) and implant chambers (lanes 4 and 8). Size markers are shown in lane 9 in (a). 


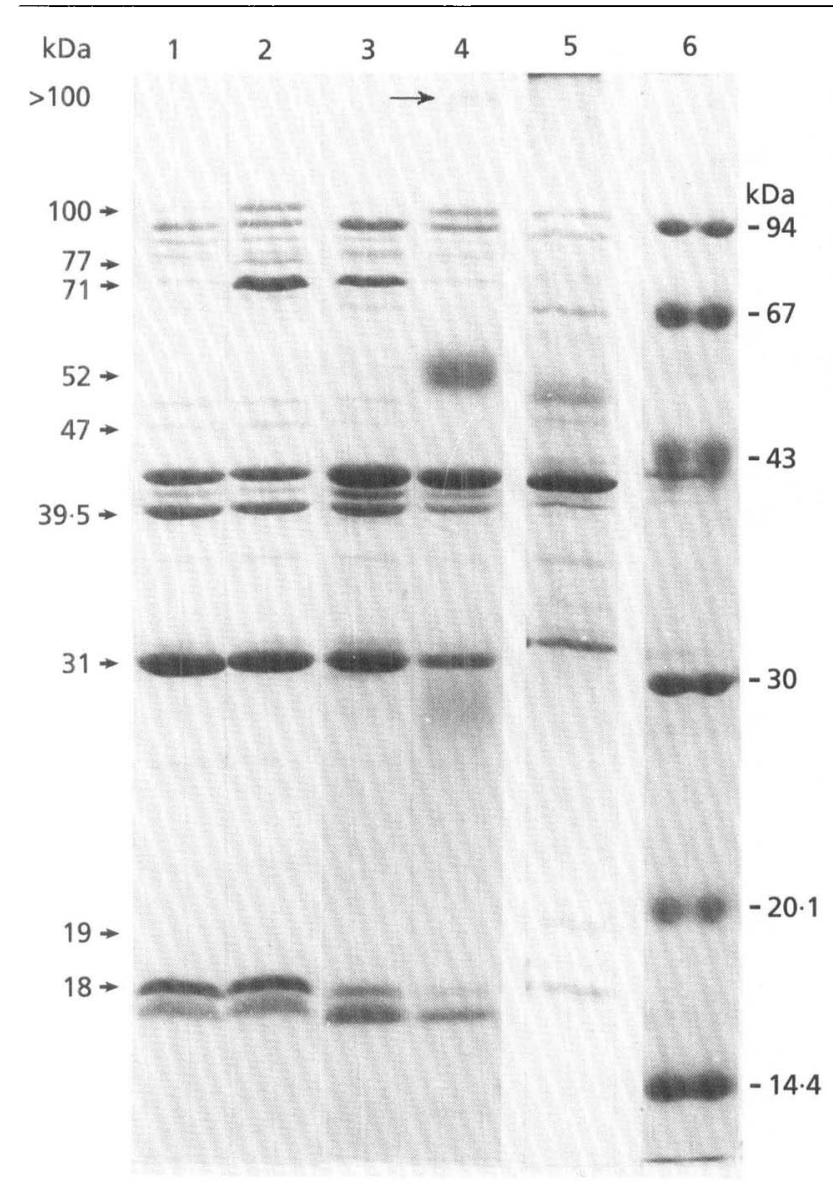

Fig. 3. Coomassie-blue-stained SDS-PAGE OMP profiles of $P$. haemolytica isolate $\mathrm{PH} 2$ grown in BHIB (lane 1), BHIB supplemented with $20 \mu \mathrm{M}$ EDDA (lane 2), foetal calf serum (lane 3), newborn calf serum (lane 4) and calf lungs (lane 5). Size markers are shown in lane 6.

When the lung- and chamber-grown OMP profiles of isolate $\mathrm{PH} 2$ were compared with the profiles of the same isolate grown under various in vitro conditions (Davies $e t$ al., 1992), it was evident that the in vivo profiles closely resembled those of $P$. baemolytica grown in newborn calf serum (Fig. 3). For example, in cells grown in newborn calf serum, there was reduced expression of the $39 \cdot 5,31$ and $18 \mathrm{kDa}$ proteins, and expression of a high-molecularmass protein of $>100 \mathrm{kDa}$ (Fig. 3, lane 4, arrowed), as there was in lung-grown bacteria (Fig. 3, lane 5). In addition, in cells grown in vivo or in newborn calf serum, expression of the iron-regulated proteins was not significantly enhanced compared with growth in vitro in the presence of EDDA (Fig. 3, lane 2). Bound IgG heavy chains $(52 \mathrm{kDa})$ were also evident in cells grown in newborn calf serum, as they were in lung- and chambergrown cells.

\section{DISCUSSION}

The present study examined the expression of OMPs in $P$. baemolytica cells obtained from the natural site of infection, i.e. the lungs, and compared them with those of cells obtained from an intraperitoneal implant chamber and from in vitro-grown cells. Differences were identified between in vivo-and in vitro-grown $P$. baemolytica that have not been described previously. In addition to enhanced production of the 71,77 and $100 \mathrm{kDa}$ iron-regulated OMPs in lung-grown cells, there was reduced expression of proteins of 18,31 and $39 \cdot 5 \mathrm{kDa}$ and apparent synthesis of a novel $19 \mathrm{kDa}$ protein compared to in vitro-grown cells. The reduced expression of the $18 \mathrm{kDa}$ protein in lung-grown cells probably correlated with the reduced expression of a $17 \mathrm{kDa}$ protein observed in a serotype A2 isolate obtained from the pleural fluid of a sheep by Donachie \& Gilmour (1988). The enhanced expression of the iron-regulated OMPs in lung-grown cells was not, however, as great as when the cells were grown in vitro under iron-restricted conditions.

When the profiles of in vitro- and lung-grown cells were examined by Western blotting, with convalescent antiserum from an experimentally infected calf, some of the differences observed in the SDS-PAGE profiles were not evident. For example, differences in the expression of the 19,31 and $39.5 \mathrm{kDa}$ proteins were not observed in Western blots. However, there were differences between in vitro- and lung-grown cells in the molecular mass range $47-100 \mathrm{kDa}$. The most significant difference, in both isolates $\mathrm{PH} 2$ and $\mathrm{PH} 10$, was the lack of recognition of the $100 \mathrm{kDa}$ protein in the lung-grown cells, in contrast to its recognition in the in vitro-grown cells, although the protein was clearly expressed in the lung-grown cells as revealed in the stained gels. These findings closely parallel those of Donachie \& Gilmour (1988), who were also unable to demonstrate immune recognition of the $100 \mathrm{kDa}$ protein in in vivo-grown cells of a serotype A2 isolate from a sheep, although the protein was visible in stained gels. Similarly, these authors were also able to demonstrate immune recognition of the $100 \mathrm{kDa}$ protein in cells grown under iron-restricted in vitro growth conditions. These results indicated, therefore, that although the $100 \mathrm{kDa}$ protein is expressed in vivo, the protein is not recognized by immune sera in Western blots. The $71 \mathrm{kDa}$ iron-regulated protein was recognized by convalescent serum in the in vivo-grown cells, but not in cells grown under iron-sufficient in vitro conditions. A $68 \mathrm{kDa}$ protein was also recognized in the lung-grown, but not in the in vitro-grown cells, whereas a $47 \mathrm{kDa}$ protein was strongly recognized in the in vitro-grown cells, but not in the lunggrown cells. A similar protein seemed to be present in the serotype A2 isolate described by Donachie \& Gilmour (1988). In Western blots, these authors described a protein of approximately the same molecular mass in in vitrogrown cells, but not in cells grown in vivo or in horse serum.

The OMP profiles of the chamber-grown cells were characterized by reduced expression of the $18 \mathrm{kDa}$ protein, and expression of a novel protein of $19 \mathrm{kDa}$, compared to in vitro-grown cells. These characteristics of chamber-grown cells confirmed that the bacteria had indeed adapted to the in vivo conditions within the chamber, because these changes also occurred in lunggrown cells. The changes demonstrate that, in some ways at least, the chamber was mimicking the conditions found 
within the bovine lung. However, chamber-grown cells differed from the lung-grown cells in a number of ways. Firstly, the 31 and $39 \cdot 5 \mathrm{kDa}$ proteins were reduced more extensively in the lung-grown cells than in the chambergrown cells. Secondly, production of the three ironregulated proteins was not enhanced to the same extent in the chamber-grown cells as in the lung-grown cells.

The findings for the iron-regulated proteins were in disagreement with those of Morck et al. (1991), who demonstrated expression of the three iron-regulated proteins in a serotype A1 isolate grown in a peritoneal implant chamber in a rabbit. However, the results were in agreement with those of Confer et al. (1992), who were unable to demonstrate expression of these proteins in a serotype A1 isolate grown in a subcutaneous chamber in a calf. It should be pointed out, however, that the profiles described by Confer et al. (1992) were whole-cell profiles, and the resolution of individual bands in the highmolecular-mass range was relatively poor. The overall antibody recognition of OMPs from chamber-grown cells was less than that for lung-grown or in vitro-grown cells. This was expected because fewer proteins were present in the stained OMP profiles of chamber-grown cells. There was much weaker antibody recognition of a $47 \mathrm{kDa}$ protein in the chamber-grown cells, compared to the in vitro-grown cells, as observed with the lung-grown cells. This observation again paralleled the findings in a serotype A2 isolate obtained from the pleural fluid of a sheep (Donachie \& Gilmour, 1988). As expected from the OMP profiles, there was no significant recognition of the iron-regulated proteins in the chamber-grown cells. Differences in the antibody recognition of proteins of 32 , 36,55 and $65 \mathrm{kDa}$ between the lung-and chamber-grown cells confirmed the fact that growth conditions were not identical in the two environments.

Finally, when the OMP profiles of the lung- and chambergrown cells of isolate $\mathrm{PH} 2$ were compared with those of cells of the same isolate grown in vitro in foetal and newborn calf serum (Davies et al., 1992), a number of common features were evident. In newborn calf serum, for example, there was reduced expression of 18,31 and $39.5 \mathrm{kDa}$ proteins; this was also observed in both the lung- and the chamber-grown cells. Reduced expression of a $17 \mathrm{kDa}$ protein was also demonstrated, by Donachie \& Gilmour (1988), in a serotype A2 isolate grown in horse serum. However, a $19 \mathrm{kDa}$ protein was not apparent in serum-grown cells, as it was in lung- and chambergrown cells. A high-molecular-mass protein of $>100 \mathrm{kDa}$ was observed in cells grown in newborn calf serum, as well as in chamber-grown cells and possibly in lunggrown cells. In foetal calf serum there was no enhanced production of the 77 or $100 \mathrm{kDa}$ proteins, whereas in newborn calf serum there was no enhanced production of the 71,77 or $100 \mathrm{kDa}$ proteins (Davies et al., 1992). It should be noted that a protein of molecular mass similar to that of the $100 \mathrm{kDa}$ protein was produced in newborn calf serum, but this protein was immunologically different from the $100 \mathrm{kDa}$ protein produced during other growth conditions (Davies et al., 1992). Similar results were observed in bacteria derived from the implant chambers, i.e. there was no enhanced production of the ironregulated proteins. Antibody recognition of the $47 \mathrm{kDa}$ protein was also reduced in cells grown in newborn calf serum (results not shown), as was observed in in vivogrown cells. Binding of IgG heavy chains occurred in both lung- and chamber-grown cells, as well as in cells grown in newborn calf serum, and has been described previously in in vivo-grown cells of both $P$. baemolytica (Sutherland et al., 1990) and Escherichia coli (Finn et al., 1982). The overall similarity of the OMP profiles of bacteria grown in vivo in the lung, and those of bacteria grown in vitro in newborn calf serum, including the binding of antibody in both environments, was highly significant. These observations suggest that the in vivo environment, during the disease process, may be partly reproduced in vitro by growing the bacteria in newborn calf serum. This finding is, perhaps, not surprising because during the disease process, as a result of inflammation, the lung alveoli are flooded with serum-like fluid. Thus, the bacteria within the lung will be growing in a serum-like medium also containing macrophages, neutrophils and various inflammatory products. Conditions in the inflamed lung will also be microaerophilic due to the alveoli becoming filled with exudate. The in vivo environment could, perhaps, be even more closely mimicked in vitro by adding cellular components to the newborn calf serum, as well as by creating microaerophilic or anaerobic growth conditions.

In summary, this study has demonstrated differences in the OMP profiles, and in the antibody recognition of OMPs, between $P$. baemolytica from the lungs of calves and cells grown in vitro. These changes involved proteins in addition to the previously recognized iron-regulated OMPs. The OMP profiles of cells obtained from an intraperitoneal implant chamber showed various changes, some of which were similar to those of the lung-grown cells, others of which were different. In particular, the iron-regulated OMPs were not highly expressed in chamber-grown cells although they were in lung-grown cells. Some of the changes observed in the lung- and chamber-grown cells were also observed in cells grown in newborn calf serum. In vivo growth of $P$. baemolytica may be mimicked most accurately in vitro by growing the bacteria in newborn calf serum.

\section{ACKNOWLEDGEMENTS}

This work was supported by AFRC grant AG17/529.

\section{REFERENCES}

Ali, Q., Davies, R. L., Parton, R., Coote, J. G. \& Gibbs, H. A. (1992). Lipopolysaccharide heterogeneity in Pasteurella baemolytica isolates from cattle and sheep. $J$ Gen Microbiol 138, 2185-2195.

Brown, M. R. W. \& Williams, P. (1985). The influence of environment on envelope properties of bacteria in infections. Annu Rev Micrabiol 39, 527-556.

Brown, M. R. W., Anwar, H. \& Lambert, P. A. (1984). Evidence that mucoid Pseudomonas aeruginosa in the cystic fibrosis lung grows under iron-restricted conditions. FEMS Microbiol Lett 21, 113-117.

Confer, A. W., Panciera, R. J. \& Mosier, D. A. (1986). Serum 
antibodies to Pasteurella haemolytica lipopolysaccharide: relationship to experimental bovine pneumonic pasteurellosis. Am J Vet Res 47, 1134-1138.

Confer, A. W., Durham, J. A. \& Clarke, C. R. (1992). Comparison of antigens of Pasteurella haemolytica serotype 1 grown in vitro and in vivo. Am J Vet Res 53, 472-476.

Craven, R. C., Confer, A. W. \& Gentry, M. J. (1991). Cloning and expression of a $30 \mathrm{kda}$ surface antigen of Pasteurella baemolytica. Vet Microbiol 27, 63-78.

Davies, R. L., Ali, Q., Parton, R., Coote, J. G., Gibbs, H. A. \& Freer, J. H. (1991). Optimal conditions for the analysis of Pasteurella baemolytica lipopolysaccharide by sodium dodecyl sulphatepolyacrylamide gel electrophoresis. FEMS Microbiol Lett 90, 23-28.

Davies, R. L., Parton, R., Coote, J. G., Gibbs, H. A. \& Freer, J. H. (1992). Outer-membrane protein and lipopolysaccharide variation in Pasteurella baemolytica serotype A1 under different growth conditions. J Gen Microbiol 138, 909-922.

Davies, R. L., Parton, R., Coote, J. G., Gibbs, H. A. \& Freer, J. H. (1994a). Evaluation of different methods for the detection of outer membrane proteins and lipopolysaccharides of Pasteurella baemolytica by immunoblotting. $J$ Immunol Methods 167, 35-45.

Davies, R. L., Gibbs, H. A., McCluskey, J., Coote, J. G., Freer, J. H. \& Parton, R. (1994b). Development of an intraperitoneal implant chamber for the study of in vivo-grown Pasteurella baemolytica in cattle. Microb Pathog 16, 423-433.

Deneer, H. G. \& Potter, A. A. (1989). Iron-repressible outer membrane proteins of Pasteurella haemolytica. J Gen Microbiol 135, 435-443.

Donachie, W. \& Gilmour, N. J. L. (1988). Sheep antibody response to cell wall antigens expressed in vivo by Pasteurella baemolytica serotype A2. FEMS Microbiol Lett 56, 271-276.

Finn, T. M., Arbuthnott, J. P. \& Dougan, G. (1982). Properties of Escherichia coli in vivo using a chamber implant system. $J$ Gen Microbiol 128, 3083-3091.

Frank, G. H. (1989). Pasteurellosis of cattle. In Pasteurella and Pasteurellosis, pp. 197-222. Edited by C. Adlam \& J. M. Rutter. London: Academic Press.

Gibbs, H. A., Allan, E. M., Wiseman, A. \& Selman, I. E. (1984). Experimental production of bovine pneumonic pasteurellosis. Res Vet Sci 37, 154-166.

Gilmour, N. J. L. \& Gilmour, J. S. (1989). Pasteurellosis of sheep. In Pasteurella and Pasteurellosis, pp. 223-262. Edited by C. Adlam \& J. M. Rutter. London: Academic Press.

Gilmour, N. J. L., Donachie, W., Sutherland, A. D., Gilmour, J. S., Jones, G. E. \& Quirie, M. (1991). Vaccination containing iron- regulated proteins of Pasteurella baemolytica A2 enhances protection against experimental pasteurellosis in lambs. Vaccine 9, 137-140.

Griffiths, E., Stevenson, P. \& Joyce, P. (1983). Pathogenic Eschericbia coli express new outer membrane proteins when growing in vivo. FEMS Microbiol Lett 16, 95-99.

Knights, J. M., Adlam, C. \& Owen, P. (1990). Characterization of envelope proteins from Pasteurella baemolytica and Pasteurella multocida. J Gen Microbiol 136, 495-505.

Laemmli, U. K. (1970). Cleavage of structural proteins during the assembly of the head of bacteriophage T4. Nature 227, 680-685.

McCluskey, J., Gibbs, H. A. \& Davies, R. L. (1994). Variation in outer-membrane protein and lipopolysaccharide profiles of Pasteurella baemolytica isolates of serotypes A1 and A2 obtained from pneumonic and healthy cattle. Microbiology 140, 807-814.

Markwell, M. A. K., Haas, S. M., Bieber, L. L. \& Tolbert, N. E. (1978). A modification of the Lowry procedure to simplify protein determination in membrane and lipoprotein samples. Anal Biochem 87, 206-210.

Morck, D. W., Ellis, B. D., Domingue, P. A. G., Olson, M. E. \& Costerton, J. W. (1991). In vivo expression of iron regulated outermembrane proteins in Pasteurella haemolytica A1. Microb Pathog 11, 373-378.

Mosier, D. A., Confer, A. W. \& Panciera, R. J. (1989). The evolution of vaccines for bovine pneumonic pasteurellosis. Res $V e t S_{c i} 47$, 1-10.

Neison, S. L. \& Frank, G. H. (1989). Purification and characterization of a $94 \mathrm{kda}$ Pasteurella baemolytica antigen. Vet Microbiol 21, 57-66.

Ogunnariwo, J. A. \& Schryvers, A. B. (1990). Iron acquisition in Pasteurella baemolytica: expression and identification of a bovinespecific transferrin receptor. Infect Immun 58, 2091-2097.

Sciortino, C. V. \& Finkelstein, R. A. (1983). Vibrio cholerae expresses iron-regulated outer membrane proteins in vivo. Infect Immun 42, 990-996.

Shreeve, B. J., Biberstein, E. L. \& Thompson, D. A. (1972). Variation in carrier rates of Pasteurella baemolytica in sheep. II. Diseased flocks. J Comp Pathol 82, 111-118.

Smith, H. (1990). Pathogenicity and the microbe in vivo. J Gen Microbiol 136, 377-383.

Sutherland, A. D., Jones, G. E. \& Poxton, I. R. (1990). The susceptibility of in vivo-grown Pasteurella baemolytica to ovine defence mechanisms in vitro. FEMS Microbiol Immunol 64, 269-278.

Received 15 April 1994; revised 10 August 1994; accepted 7 September 1994. 